\title{
PROFITABILITY AND EFFICIENCY OF BAMBARA GROUNDNUT PRODUCTION IN NIGERIA: A CASE STUDY
}

\author{
Unekwu ONUCHE *1 (iD), Stephen Jimoh IBITOYE ${ }^{2}$ (i) , Thomas ANTHONY ${ }^{2}$ (iD
}

\author{
Address: \\ ${ }^{1}$ Department of Agricultural Economics and Extension, University of Africa, Toru Orua, Bayelsa, Nigeria. \\ ${ }^{2}$ Department of Agricultural Economics and Extension, Kogi state University, Anyigba, Nigeria \\ Corresponding Author's email: kanonuche@gmail.com
}

\begin{abstract}
Research Background: Although it is a highly nutritious and climate resistant crop, bambara groundnut is described as a neglected and under-utilized crop in most countries including Nigeria where its production is in the hands of some smallholder farmers. Empirical facts on the profitability as well as the technical efficiency of bambara groundnut production in Kogi state, Nigeria, where it serves as an important source of food and income, are unknown. These facts, when known, can draw the attention of stakeholders to intervention areas.

Purpose of the article: The research was undertaken to provide factual data through empirical analyses on the cost, returns and technical efficiency of smallholder bambara groundnut farmers in the area, in to order elicit interest in the neglected crop. Such attention may aid in the expansion of the crop's production through interventions in identified areas of concern.

Methods: A five-stage sampling technique was employed in the random selection of 120 farmers for questionnaire administration in order to obtain the requisite data. Data on cost and returns were subjected to Gross Margin and Net Return on Investment analyses while the Cobb-Douglas Stochastic Frontier Production Function was employed in analysing technical efficiency.

Findings and value added: Producers of bambara groundnut in the area are small scale farmers who are old, poorly educated and have large families. Cost and returns analysis showed that labour had the highest percentage of Total Variable Cost (78.00\%). The venture, with a gross margin of -11,601.87 Nigerian Naira (-60.31 USD) and Net Returns on Investment of 0.79 , is unprofitable. Experience and education affect the moderately high technical efficiency level which on the average is $71.2 \%$. Bambara groundnut production in the area can be made profitable through labour cost reduction and improvement in average efficiency level by $28.8 \%$. The provision of machinery to help reduce labour cost, in addition to special policy attention that will enhance improvements in education and extension services will reduce inefficiency and improve profitability.
\end{abstract}

Key words: profitability; efficiency; bambara groundnut; production JEL: Q12; C13

\section{INTRODUCTION}

Bambara groundnut (Vigna subterranean $(l)$ verdc) is a seed of Africa origin used locally as a vegetable. It is a herbaceous short-leaved annual crop plant of about $15 \mathrm{~cm}$ high with numerous nitrogen fixing nodules on the roots, thus contributing to land improvement (Yakubu et al., 2010). The crop is special for a number of reasons. First it is an important legume in semi-arid Africa and is resistant to high temperature and drought (Abejide et al., 2017; Mabhaudhi and Modi; 2013). Second, it is also suitable for marginal soils where other leguminous crops cannot be grown as it makes very little demand on the soil (Yamaguchi, 1983). Thus, it is not prone to the risk of total harvest failure even in low and uncertain rainfall regions as it can perform reasonably in the event of drought (Mayes et al., 2019). Furthermore, this crop's susceptibility to insect and disease infestation is low (Tweneboah, 2000). In addition, Mayes et al. (2019) and
Berchie et al. (2010) have describe it as climate resilience crop. Again, the plant is useful in sustaining the plant habitat as it increases the fertility of soil and brings about high yields of other crops cultivated around it without the application of fertilizer. Hence it is a reliable alternative food and income source in the face of the negative consequences of climate change.

Nutritionally, the crop holds great promises. As the quest for plant with nutritional properties continues to receive attention, bambara groundnut which contains protein $(15-25 \%)$, carbohydrate (49-63.5\%) and lipids (4.5-7.4\%) (Murevanhema and Jideani, 2013) and can be consumed at different stages of maturation has become handy in some areas. Its high level of lysine (Mune et al., 2011) makes it a good complement for other food sources. Nutritionally, in comparison with other protein sources, bambara groundnut performs well. The raw crop contains 390 calories per100 grams, making it higher in energy than cowpea (343 calories), kidney (333 calories), broadbean 
(341 calories) and chickpea (364 calories). It is also higher than any of the above mentioned food items in terms of carbohydrates and fats and is a rich source of protein (Azam-Ali et al., 2001; Mazahib et al., 2013). Thus, it can be utilized in the preparation of baby food (Atiku $\boldsymbol{e t}$ al., 2004). The roots, leaves and seeds contain high levels of macro nutrients which are suitable for use in the production of animal feed (Food and Agriculture Organisation, n.d, Atiku et al., 2004). In fact, as a "complete food" (Murevanhema and Jideani, 2013), which can be depended on for all the nutritional requirements for healthy livings, it is an important addition to the diet of poverty stricken folks who are unable to sustainably afford expensive animal protein sources (Food and Agriculture Organisation, n.d). It has also been reported that bambara groundnut has potentials for industrial purposes (Ibrahin and Ogunwusi, 2016, Atiku et al., 2004) and has been experimented with in feeding of livestock (Nji et al., 2003, 2004).

Unlike cowpeas, and some other legumes, but like groundnut, damage to seeds by insects is uncommon because the pods are buried underneath the soil. This makes the production of bambara groundnut less costly in terms of the use of insecticides which is heavily dependent up on in the cultivation of other legumes. In relation to this, the rejection suffered by cowpeas in international market owing to presence of chemical residuals beyond acceptable limits is not likely to be experienced by bambara groundnut. Furthermore, the cost of these chemicals which increases production cost in cowpeas and some other legumes is also minimized in bambara groundnut production. The yield of bambara groundnut which ranges from $300 \mathrm{~kg}-600 \mathrm{~kg} / \mathrm{ha}$ compares well with its closest rival, cowpeas, which has a yield of $400 \mathrm{~kg}-$ 600kg/ha (Azam-Ali et al., 2001). Hence on climatic, nutritional, health, foreign exchange earnings, input cost and production potentialities considerations, bambara groundnut is a reliable alternative source of plant protein and income.

Bambara groundnut is common in Cameroon and Central African Republic and has been introduced to several African countries. Cultivation is however not common in Nigeria where it comes behind beans, groundnut and soybeans in terms of production. In fact, it doesn't appear to be a crop that elicits national policy attention. Hence, the huge potentials of this crop continue to elude Nigeria and Nigerians. Dansi et al. (2012) observed that despite the nutritional value of bambara groundnut it is still considered, neglected and underutilized in most countries and Nigeria where its production like most food crops, is in the hands of some smallholder framers. Generally, it is one of the Neglected and underutilized species (NUS). Its position in Nigeria may be similar to what obtains in some African countries like in Ghana and Benin where it is considered a neglected crop (Adzawla et al., 2015, Dansi et al., 2012), in Tanzania, where it is relegated to second fiddle crop (Mkandawire and Sibuga, 2002) or in Kenya, where it is going into extinction (Korir et al., 2011).

It has however found appreciable attention in eastern Kogi state, eastern and north-eastern part of the country where it is used in the preparation of a lot of local delicacies including cake, dumpling (okpa), porridge, pan cake, snacks (boiled fresh or roasted dry), milk, baby food, among others. In Kogi east, it is of strategic economic value during yuletides as farmers rely on its sales to buy Christmas items. The crop also has medicinal value among locals (Atiku, 2000). The underutilization of this dependable alternative energy and protein source with the aforementioned agronomic, nutrition and derived economic advantages over its rivals needs to be overturned (Dansi et al., 2012, Azam-Ali et al., 2001 Mkandawire and Sibuga, 2002, Adzawla et al., 2015, Ibrahim et al., 2018).

While making a case for increased production of this crop in Nigeria is important, caution should be exercised in the ordering of priorities. It is important to know how producers of this crop have been faring in terms of profits and how efficient they have been in the production process, technically speaking. For, if the production of this crop is unprofitable, how can we convince farmers to increase their production or encourage others to engage in its production? And, if resources are wasted in the production process- as seen in below-the-frontier output scenario, how sustainable will it be to continue to produce at the same level of use of existing technique in the application of resources?

A poor profit margin can be a discouraging factor and could cause farmers to reduce their production scale and prevent others from venturing into it. Hence an understanding of the profitability of the crop is important. Aside profitability, another factor that can engender the understanding of the sustainability of a crop enterprise is the production efficiency. Low agricultural productivity has led to the poor performance of the food subsector leading to unfavourable food balance sheet (Oyinbo et al., 2015). Technical efficiency indicates whether a farm makes the best use of available technology. It reflects the ability of a farm to obtain maximum output from a given set of inputs (Coelli and Rao, 2005). Studies on technical efficiency of other commodities in different location across the country and elsewhere have revealed varying levels of technical efficiency estimates (Onuche $\boldsymbol{e t} \boldsymbol{a l}$., 2015; Ekunwe and Emokaro, 2009; Ali and Khan 2014; Ogundari, 2008; Ogundari and Ojo, 2007). The results of these studies cannot be extrapolated for other parts of the country and in fact other crops. Area specific and in fact crop specific studies are better positioned to provide peculiar information as regards the commodity in the area in order to furnish policy makers with the right information for a specific area Asrat and Simane (2018) and commodity. In Nigeria little research has been conducted on this crop. Empirical findings on profitability and technical efficiency have been reported by Mohammed (2016) and Ani et al. (2013) for some states in Nigeria, while technical efficiency estimates have also been reported for other African countries like Ghana (Adzawla et al., 2015) and Kenya (Korir et al., 2011). As at yet, we are not aware of any study on profitability and, or technical efficiency of bambara groundnut production in Kogi state, central Nigeria. It is imperative therefore to also examine how efficiently farmers in the study area are using existing bundle of farm inputs and the factors 
influencing their efficiency levels, in addition to the profitability of the venture. Hence, the objectives of this study were to analyse the cost, returns and the technical efficiency of small holders bambara groundnut farmers in eastern Kogi state.

A study of this nature is important for the sustainability of agricultural production. Traditionally, profit maximization and efficiency are important issues that small holder farmers do not pay serious attention to. Schultz (1964) hypothesized that farm households in developing countries are "poor but efficient". This gave rise to a long debate among economists and the advent of empirical works for testing it. He described the peasant production system as having a profit-maximization behaviour, where efficiency is defined in a context of perfect competition. But it must be borne in mind that, against the profit maximization theory, exists arguments on trade-offs of profits for other household goals, as well as the role of uncertainty and risk in farm household production decisions. It however largely remains that rural farm households in Nigeria are generally profit maximizers.

Maximization of returns is an important factor in the sustainability of farm ventures especially where the goal is to make money. In the absence of good profit margin, discouragement may set in, restricting production to subsistence level. This in turn constrains economic development by way of under-production and attendant unemployment. Works on arable production in Nigeria have revealed positive margins Ohajianya and Onyenweaku (2003), Ewuziem and Onyenobi (2012), Segun-Olasami and Bamire (2010).

Efficient allocation of resources in order to assist farmers attain their objectives has been one of the frontline issues in micro level agriculture. The level of technical efficiency of a firm is characterized by the relationship between observed output and some ideal expected output (Onuche et al., 2015). The measurement of firm specific technical efficiency is based on the deviation of observed output from efficient production frontier (Battese and Coelli, 1995). Technical efficiency can either be output or input oriented. An output oriented technical efficiency is achieved when the maximum amount of an output is produced for a given set of input while an input -oriented technical efficiency concerns the minimum amount of input are required to produce a given output level (Farrell, 1957). Therefore, technical efficiency is derived from production function or production possibility frontiers. The closer a farmer's output is to this frontier, the more technically efficient he is.

Several approaches have been developed and followed in estimating firm level technical efficiency. These include the Data Envelopment Analysis (DEA), the Malmquist productivity index and the stochastic frontiers. Charnes et al. (1978) was the first to apply the DEA in efficiency measurement technique. Characteristics of this approach to efficiency measurement have been reported by (Onuche $\boldsymbol{e t} \boldsymbol{a l} ., \mathbf{2 0 1 5})$. The approach has been adopted by Nin et al. (2003) and Coelli (1995). Its shortcomings are basically that recommendation of input or output levels are in fixed proportions and its inability to identify sources of inefficiency.
The Malmquist productivity index introduced by Caves $\boldsymbol{e t}$ al. (1982a, 1982b), is a binary comparison of two entities. Farrell et al. (1957) extended the index to allow for productivity into change in technical efficiency and technological change. The approach measures productivity change, by comparing observed change in output with the imputed change in output that would have been possible from the observed input changes. The imputation is based on the production possibility set for either the current or the subsequent period. During the computations, it makes use of DEA to generate the ratio of two distance functions (input and output distance functions) and their geometric means.

The stochastic frontier approach specifies the relationship between output and input levels using two error terms: normal error term and technical inefficiency. The approach estimates technical efficiency through maximum likelihood of the production function subject to these error terms (Aigner et al., 1977) and Meeusen and Van den Broeck (1977). The stochastic frontier approach to technical efficiency estimation is the most preferred in agricultural economics because the basic assumption of the non -parametric approach and deterministic frontiers that all deviations from the frontier are due to farms inefficiency is highly unrealistic in the agriculture. Also, aside estimating firm level efficiencies, it is capable of identifying the factors of technical inefficiency. Mulinga (2013) Njeru (2010) Onuche et al. (2015) have estimated levels and factors of technical efficiency in agricultural production using this approach. Korir et al. (2011) have applied the stochastic frontier to the study of bambara groundnut in Ghana (Adzawla et al. (2015) and Kenya (Korir et al., 2011) and in Nigeria (Mohammed, 2016, Ani et al., 2013)

\section{DATA AND METHODS}

\section{Sampling Procedure}

A five stage purposive and random sampling procedure was used for this study. First, Kogi state was purposively selected due to the presence of sizeable bambara groundnut production and trade. Then Kogi east senatorial district was also purposively selected out of the three senatorial districts of the state. It was selected because the district is known for more cultivation of bambara groundnut than the other two districts. Two local governments- Ankpa and Olamaboro- where the production of bambara groundnut is pronounced were then selected. Two wards were then selected from each of these local governments. Thereafter, 2 farming communities were selected from each of the 2 wards making 8 farming communities in all for the study. Sampling frame was obtained from the Agricultural Development Programme (ADP) office covering the area. An average of 15 farmers from each of the selected community were randomly selected for questionnaire administration. Thus the total number of farmers selected was 120 . To make room for loss or poor completion $5 \%$ additional questionnaire were added. In all, a total of 126 bambara groundnut farmers were interviewed using a structured questionnaire. Only 122 were however duly filled and returned. Analysis was however based on 120 completed questionnaires. 


\section{Method of Data Analysis}

The cost and returns of the smallholder bambara nut farmers was analysed using Gross Margin (GM) and Net Return on Investment (NRI) (Nkamigbo et al., 2014), while the Cobb-Douglas Stochastic Frontier Production Function was employed in the analysis of the technical efficiency. Estimated farm level technical efficiencies were presented using frequency table and bar chart.

Gross Margin (GM) analysis is used to estimate the cost and returns or profitability enterprises under the assumption that fixed cost constitute a negligible components of the Total Cost-TC in small scale production (Abubakar and Olukosi, 2008). In crop enterprises, analysis is conducted on per hectare basis. The Total Revenue (TR) is the farm gate value of the output from the farm. It is given by physical quantity of output multiplied by the unit price. Total Variable Cost (TVC) on the other hand includes total expenditure on variable inputs like seeds, agrochemicals, labour etc. The Gross Margin (GM) of bambara groundnut production enterprises in the area was expressed as: GM=TR-TVC; A positive GM is indicative the profit while a negative one indicates loss. Gross Margin analysis is plausible in the understanding of farm firm profitability in situations where fixed costs are minimal as is the case with small holder bambara groundnut production in the area. Net Return on Investment (NRI), is the ratio of the TR to Total Cost (TC) and is an indicator of returns to investment. An estimated NRI greater than unity is indicative of positive profit while a lower-than unity NRI points to negative profit or loss. An NRI of unity indicates that TC=TR. Note, that at the time of this study in 2015, 1 US dollar $($ USD) $=192.4$ Nigerian Naira $(\mathrm{NGN})$ on the average.

A stochastic frontier production function (SFPF) can be specified for cross-sectional data with an error term consisting 2 components: one that accounts for technical inefficiency $\left(V_{i}\right)$ and the other which accounts for random effects $\left(U_{i}\right)$.

Following Korir et al. (2011), the SFPS used for the analysis of the technical efficiency of bambara groundnut farmers was presented in term of Cobb- Douglas production functional form as in Eq. 1 .

$Y=\beta_{0}+\beta_{1} \ln X_{1}+\beta_{2} \ln X_{2}+\beta_{3} \ln X_{3}+\beta_{4} \ln X_{4}+$
$\beta_{4} \ln X_{4}+\beta_{5} \ln X_{4}+V_{i}-U_{i}$

Where:

$Y$ Bambara groundnut output $(\mathrm{kg})$;

$X_{1}$ Farm size (ha);

$X_{2}$ Labour input (man-days);

$X_{3}$ Quantity of seed planted $(\mathrm{kg})$;

$X_{4}$ Quantity of pesticides (litres);

$X_{5}$ Quantity of fertilizer used $(\mathrm{kg})$;

$V_{i}-U_{i}$ error term;

$\beta_{i}$ are the coefficients.

Error term; (i.e. the unknown scalar parameter to be estimated. This error term accounts for random variation in output due to factors outside the farmer's control such as weather, diseases. It is assumed to be independently and identically distributed $\left(U, \delta^{2} U\right)$, a one sided component and independent of $U . U=0$ reflects non-negative random variable associated with technical inefficiency in production and is assumed to be half normal (independently and identically distributed (iid)) $\mathrm{N}\left(U, \delta^{2} U\right)$ where the conditional mean is assumed to be related to term and farmers-related socio-economic characteristics.

The inefficiency model is specified as Eq. 2.

$U_{i}=\delta_{0}+\delta_{1} \ln Z_{1}+\delta_{2} \ln Z_{2}+\delta_{3} \ln Z_{3}+\delta_{4} \ln Z_{4}$

Where:

$U_{i}$ inefficiency effect;

$Z_{1}$ Family size (number of persons in a household);

$\mathrm{Z}_{2}$ Farming experience (years of bambara groundnut production);

$Z_{3}$ Level of education (years of formal schooling);

$Z_{4}$ Age (in years);

$\delta_{i}$ parameters to be obtained through maximum likelihood estimation.

All variables were analysed in their natural $\operatorname{logs}(\ln )$.

\section{RESULTS AND DISCUSSION}

\section{Key demographic characteristics of bambara groundnut farmers in Kogi state}

The key demographic variables used in this study are summarized in Table 1. The average land used for bambara groundnut cultivation in the area is half a hectare and reflects the small holder nature of the enterprise in the area. Average age of 43 years suggests an aging population. This is close, to 39 years found by (Mohammed, 2016) in Kaduna state.

This is a common observation in Nigerian agriculture where production is in the hands of the aging segment of the population. Furthermore, formal education level is about 5 years of formal schooling and indicates a poor level of education among the farmers in the area. Formal education has serious implication for efficiency because of the ability and exposure it confers on the farmer in the understanding of improved techniques. The household size which ranges from 3 to 15 (the average number of usual residents - household members per household) and has a mean of 8 , is generally higher than the nation average which is about seven. On the average, experience in bambara nut production (14.6 years) is high. In sum, bambara groundnut production is undertaken on small scale basis by an experienced aging population who are poorly educated and have large family sizes.

\section{Cost and return of small holder bambara groundnut production Kogi state}

Profitability analysis of bambara groundnut production in the study area indicate a farmer on the average incurred variable costs of 89,600.77 NGN (Nigerian Naira) (465.71 USD), with labour accounting for as high as $78 \%$ of TVC (Table 2). This is contrary to the $26 \%$ found in Kaduna state by Mohammed (2016). Explanation for this may be found in the fact that the two states are dissimilar demographically and agro-climatologically. 
Table 1: Descriptive statistics of key demographic characteristics of bambara groundnut farmers in Kogi state.

\begin{tabular}{lrrrr}
\hline Variable & Sample Mean & Std.Dev. & Minimum & Maximum \\
\hline Cultivated land size (ha) & 0.49 & 0.42 & 0.30 & 1.25 \\
Age (years) & 42.73 & 17.4 & 18 & 67 \\
Years of formal education & 4.66 & 6.63 & 0 & 15 \\
Household size & 7.67 & 6.94 & 3 & 15 \\
Experience (years) & 14.6 & 7.91 & 3 & 23 \\
\hline
\end{tabular}

Source: Authors' computation from field survey, 2015

Table 2: Average per ha cost and return of small holder bambara groundnut production Kogi state.

\begin{tabular}{lll}
\hline Variable Inputs & $\begin{array}{l}\text { Cost, revenue } \\
\text { (NGN/ha) }\end{array}$ & $\begin{array}{l}\text { Cost, revenue, } \\
\text { (USD/ha) } \\
\text { and ratio }\end{array}$ \\
\hline
\end{tabular}

$\begin{array}{lrr}\begin{array}{l}\text { Variable costs } \\ \text { (a). Labour }\end{array} & 69,890.71 & 363.23 \\ & (78.00 \% \text { of TVC) } & \\ \text { (b). Seed } & 15,929.55 & 82.79 \\ \text { (c). Agrochemicals } & 3,049.59 & 15.85 \\ \text { (d). Others } & 730.92 & 3.80 \\ \text { TVC } & 89,600.77 & 465.71 \\ \text { Fixed Cost } & & \\ \text { Depreciation } & 8,938.18 & 46.46 \\ \text { TFC } & 8,938.18 & 46.46 \\ \text { REVENUE } & 77,998.90 & 405.40 \\ \text { TC=TVC+TFC } & 98,538.90 & 512.16 \\ \text { GM =TR-TVC } & -11,601.87 & -60.31 \\ \text { Net Returns on Investment } & 0.79 & 0.79 \\ \text { (TR/TC) } & & \end{array}$

(TR/TC)

Source: Authors' computation from field survey, 2015.

According to the 2006 census, Kaduna state's population is 6,133,503 persons, while that of Kogi is 3,314043 persons. Furthermore, discrepancies in poverty and unemployment rates between the two states have been documented. While the poverty rate based on Purchasing Power Parity as at 2010 was $74.2 \%$ for Kaduna state (Nigeria-Kaduna, n.d), that of Kogi state was $72.5 \%$ (Nigeria-Kogi, n.d). In addition, estimate for unemployment rate in Kaduna state as at 2018 was $26.8 \%$ (Nigeria-Kaduna, n.d) while that of Kogi state was $19.7 \%$ (Nigeria-Kogi, n.d). The difference in labour cost components in bambara groundnut production in these states may not be unrelated to the dissimilarities in the key indices mentioned above. For instance, compared to Kaduna state, lower population, poverty and unemployment rates in Kogi state may put some pressure on her available supply of labour, pushing up labour costs. In addition, the agro-climatic conditions of the two areas may play a role in total costs of labour. Kogi is in the guinea savannah which is characterized by wooded land, thicker bushes and higher rainfall and may require more labour for land clearing and weeding than Kaduna state in the Sudan savannah which characterized by shorter trees and less dense vegetation and lower rainfall.

The average per hectare revenue of bambara groundnut revenue is 77,998.9 NGN (405.40 USD). Thus, bambara groundnut production in the area returns a margin of $-11,601.87$ NGN (-60.31 USD) and an NRI of 0.79 , implying non-profitability. While the GM indicates per ha loss of 1,601.87 NGN (60.31 USD), the NRI indicates a loss of $21 \mathrm{k}$ for every naira invested. Ani et al. (2013) found a GM of 18,958.83 NGN (98.54 USD) /ha in Benue state while a margin of 113,155 NGN (588.12 USD) was found in Kaduna state (Mohammed, 2016) who also reported a Return on Naira Invested of 2.27.

Considering the proportion of labour cost in the total variable cost, in comparison with that of the Kaduna state survey, a reduction in labour cost will definitely increase the profitability level of the crop. It is to be noted that the approach to measuring cost of labour was the opportunity cost approach as the labour was basically provided by family members.

Maximum likelihood estimator (MLE) estimates of technical efficiency of bambara groundnut production in Kogi state.

The result of the Cobb-Douglas stochastic frontier estimation using maximum likelihood estimation is presented in Table 3. The statistical significance of sigma squared indicates the appropriateness of the model. The result of the MLE estimates on bambara groundnut production shows that the performance of the model in terms of sigma squared and gamma are significantly different from zero at $10 \%$ and $1 \%$ level of significance. The variance parameter for sigma squared and gamma are 0.441 and 0.848 respectively. The sigma squared indicates the goodness of fit and correctness of the distributional form assumed for the composite error term. The gamma estimates indicate the systematic variance that is unexplained by the production function and is the dominant source of random errors the value of gamma 0.848 means that about $84.8 \%$ of the variation in bambara 
groundnut output is attributed to variation in technical efficiency of farmers. The maximum likelihood estimates of the stochastic production indicate that the elasticity of production with respect to farm size, labour, quantity of seeds and quantity of fertilizer $(0.777,0.271,0.366$, and 0.027 ) respectively were positive and significant at $1 \%$ level of significance and are therefore the major determinants in bambara groundnut production. This is consistent with the findings of Nwaru and Ndukwu (2011) that fertilizer, capital and farm size positively affects output. The sum of the coefficients (output elasticity) of the variables is 1.381 , indicating an increasing return to scale.

Contrary to a priori expectation, farming experience has positive relationship with technical inefficiency. This relationship means that farmers' experience increases inefficiency in bambara groundnut production. It might also be related to the profitability level of the crop. This could be attributed to the reluctance of farmers to adopt innovation or knowledge required to increase the efficiency of agricultural production. This contrast the finding of Amodu et al. (2011), Simonyan et al. (2012), and Nurudeen and Rasaki (2011). Education on the other hand has a negative relationship with technical inefficiency, implying that inefficiency of bambara groundnut production reduces with increase in farmers' educational attainment. Among other things, education enhances the capacity of farmers to comprehend literature on agronomic practices and better organise their enterprises. This finding agrees with Ali and Khan (2014), Adzawla et al. (2015), Mulinga (2013), Musaba and Bwacha (2014), Amodu et al. (2011) and Simonyan et al. (2012), but contrasts Onuche et al. (2015).

\section{Levels of technical efficiency of bambara groundnut} farmers in Kogi state

The levels of technical efficiency of bambara groundnut farmers presented in Table 4 show that the farmers differ substantially in their level of technical efficiency which range from less than 0.31 to 0.91 and above. Ungrouped figures reveal a minimum efficiency of $0.21(21 \%)$ and a maximum efficiency level of $0.95(95 \%)$ while mean efficiency was $71.2 \%$. The result shows that $3.3 \%$ of bambara groundnut farmers in the area have technical efficiency level of less than 0.31 , while $61.7 \%$ have estimates ranging from 0.71 to 0.9 . Only $3.3 \%$ have technical efficiency level of 0.91 and above.

Table 3: Maximum likelihood estimator (MLE) estimates of technical efficiency of bambara groundnut production in Kogi state.

\begin{tabular}{|c|c|c|c|}
\hline Variable & Parameter & Coefficient & t-ratio \\
\hline \multicolumn{4}{|l|}{ Production function } \\
\hline Constant & $\beta_{0}$ & 4.96 & 13.7 \\
\hline Farm size & $\beta_{1}$ & $0.777 * * *$ & 7.48 \\
\hline Labour & $\beta_{2}$ & $0.271 * * *$ & 3.68 \\
\hline Quantity of seed planted & $\beta_{3}$ & $0.306 * * *$ & 3.21 \\
\hline Quantity of pesticides & $\beta_{4}$ & 0.0004 & 0.018 \\
\hline $\begin{array}{l}\text { Quantity of fertilizer } \\
\text { Inefficiency model }\end{array}$ & $\beta_{5}$ & $0.027 * * *$ & 2.81 \\
\hline Constant & $\delta_{0}$ & 7.44 & 1.99 \\
\hline Family size & $\delta_{1}$ & 0.14 & 0.46 \\
\hline Farming experience & $\delta_{2}$ & $0.92 *$ & 1.65 \\
\hline Age & $\delta_{3}$ & -0.01 & -0.19 \\
\hline Education & $\delta_{4}$ & $-2.75^{*}$ & -1.86 \\
\hline \multicolumn{4}{|l|}{ Diagnostic statistics } \\
\hline Sigma square & $S^{2}$ & $0.441 *$ & 1.85 \\
\hline Gamma & $\Gamma$ & $0.848 * * *$ & 7.36 \\
\hline
\end{tabular}

Log likelihood function $=-58.02 ;$ LR test $=-25$

Note: ***significant at $1 \%$ level, *significant at $10 \%$ level.

Source: Authors' computation from field Survey, 2015

Table 4: Levels of technical efficiency (TE) of bambara groundnut farmers in Kogi state.

\begin{tabular}{llll}
\hline TE estimate & Frequency & $\%$ & Cum. \% \\
\hline Up to 0.30 & 4 & 3.3 & 3.3 \\
$0.31-0.50$ & 16 & 13.3 & 16.7 \\
$0.51-0.70$ & 22 & 18.3 & 35.0 \\
$0.71-0.90$ & 74 & 61.7 & 96.7 \\
Above 0.90 & 4 & 3.3 & 100.0 \\
Total & 120 & 100.0 & \\
Minimum & 0.21 & & \\
Maximum & 0.95 & & \\
Mean & 0.712 & & \\
\hline
\end{tabular}

Source: Authors' computation from field survey, 2015 


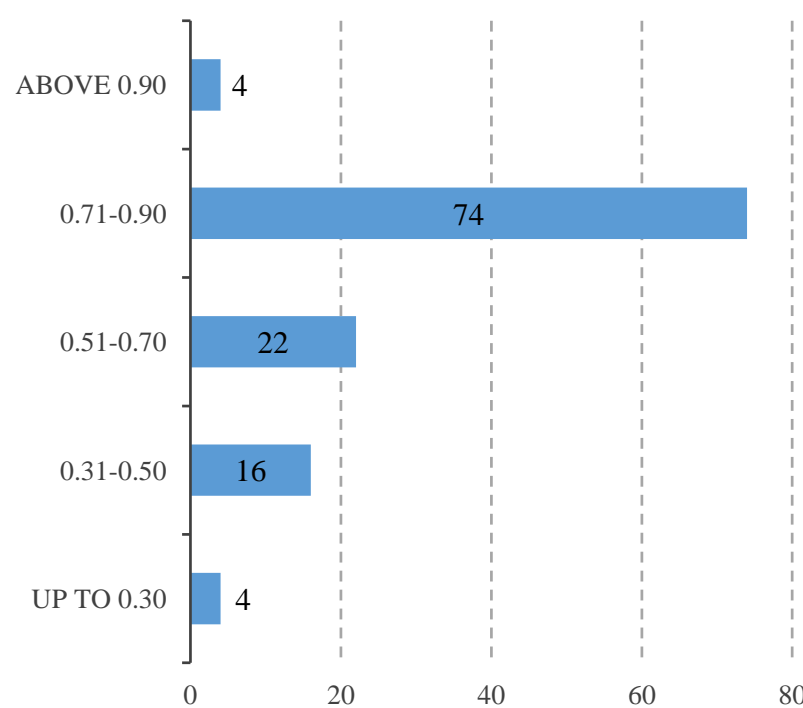

Figure 1: Levels of Technical Efficiency of the Respondents Source: Analysis of Field data, 2015

The mean efficiency of $71.2 \%$ above implies that the average small holder farmers in the study area will have to reduce inefficiency by $28.8 \%$ in other to operate on the frontier. In another way, the average technical efficiency of $71.2 \%$ indicate that the average farmer will have to increase output by $28.8 \%$ with the present level of inputs bundle in order to reach the production frontier. For the most inefficient small holder farmers with minimum technical efficiency of $21 \%$ to be on the frontier, they will need to achieve $79 \%$ more productivity or efficiency. In the case of the most technically efficient smallholder farmer with a maximum technical efficiency of $95 \%$, he needs to reduce inefficiency by $5 \%$ to be on the frontier. Technical estimates of $80 \%$ of the farmers range from 51 to $95 \%$, implying a good level of utilization of prevailing bambara groundnut production technology in the area. Ani et al. (2013) found a mean technical efficiency of $70 \%$ for the same crop in Benue state. Mohammed (2016) found a mean technical efficiency $70 \%$ for the crop in Kaduna state, Nigeria. Korir et al. (2011) found a poorer Technical efficiency of $38.4 \%$ indicating that bambara groundnut production was more in inefficient in Kenya where the crop is going into extinction. Adzawla et al. (2015) in Ghana, found a much higher average Technical efficiency of $83 \%$.

In this study, the average farmer needs about $25.1 \%$ i.e. $\left[1-\frac{0.712}{0.95} * 100\right]$ increase in his total production to be at par with the most technically efficient farmer. The least efficient farmer needs $77.9 \%$ i.e. $\left[1-\frac{0.21}{0.95} * 100\right.$ to attain the efficiency level of the most technically efficient farmer. In all, for the average farmer to attain the frontier, an average of $28.8 \%$ increase in output is required. The high level of inefficiency of about $30 \%$ may not be unconnected to the poor attention given to bambara groundnut production by government, researchers, breeders and extension agents. While researchers are deeply involved in the development of higher yielding strand of legumes as in cowpeas and soybeans, it is not on records that serious attention is being given to bambara groundnut. Obviously the importance of this crop has not been appreciated by Nigerian policy makers.

\section{CONCLUSION}

The study found negative profitability estimates for bambara groundnut production in Kogi state. Technical efficiency estimate however compares well with those found elsewhere in the country and on the continent. While profitability was poor, efficiency was moderately high and encouraging. The negative profitability could be a discouraging factor for primary producers although it may favour other segments of the production-marketing chain. Technical inefficiency on the other hand connotes poor productivity which translates to resource wastage and attendant poverty. There is therefore the need to improve on the profitability of the venture and its technical efficiency in order to ensure sustainable production so that the nation can benefit from the nutritional and economic advantages the crop confers-especially as a climate change resilient, and dependable malnutrition mitigating crop. Intervention by government in making the production of the crop less labour intensive through the provision of farm machines will help reduce labour cost and improve its profitability. Improving opportunities for formal education will positively impact technical efficiency. Availability of improved extension services and technology will also elicit reduction in technical inefficiency. Government and researchers will also need to improve the prospects of the crop through serious commitment to research and production technology. As it stands now, the crop suffers neglect from government in that while many tropical crops like cassava, yam, and cowpea, among others are mandate crops for research institutes across the country, bambara groundnut has not enjoyed such attention. The crop will benefit from its inclusion as a mandate crop in related research institutes. Aside research activities in these institutes for yield 
improvements, due publicity should be given to this crop given its importance as a highly nutritious food crop that does not make much demand on soil and water but helps in soil improvement.

\section{REFERENCES}

ABUBAKAR, M. I., \& OLUKOSI, J. O. (2008). Analysis of cowpea production under the national program on food security in Argungu local government area of Kebbi state. Nigerian Journal of Basic and Applied Sciences, 16(2), 243-247.

ABEJIDE, D. R., FALUSI, A. O., ADEBOLA, M. O., GANA, A. S., MUHAMMAD, L. M., \& GADO, A. A. (2017). Evaluation of drought tolerance of some Nigerian bambara groundnut (Vigna subterranean) land races. International Journal of Applied Biological Research, 8(2), 142-148.

ADZAWLA, W., DONKOH, S. A., NYARKO, G., O'REILLY, P., OLAYIDE, O. E \& AWAI, P. E. (2015). Technical efficiency of Bambara groundnut production in Northern Ghana. UDS International Journal of Development, 2(2), 37-49. http://www.udsijd.org

AIGNER, D. J., LOVELL, C. A. K., \& SCHMIDT, P. (1977). Formulation and estimation of stochastic frontier production functions model. Journal of Econometrics, 6(1), 21-37. https://doi.org/10.1016/0304-4076(77)90052-5

ALI, S., \& KHAN, M. (2014). Technical efficiency of Wheat production in district Peshawar Pakhtunkhwa Pakistan. Sarhad Journal of Agriculture, 30(4), 433441.

AMODU, M. Y., OWOLABI, J. O., \& ADEOLA, S. S. (2011). Resource use efficiency in part-time food crop production: the stochastic frontier approach. Nigerian Journal of Basic and Applied Science, 19(1), 102- 110

ASRAT, P., \& SIMANE, B. (2018). Farmers' perception of climate changes and adaptation strategies in the Dabus Watershed, North-West Ethiopia. Ecological Processes, 7(7):1

13. https://doi.org/10.1186/s13717-018-0118-8

ATIKU, A. A. (2000). Bambara groundnut processing and storage practices in north eastern Nigeria. M.A seminar thesis. Department of Agricultural Engineering, University of Maiduguri.

ATIKU, A. A., AViarA, N. A., \& HAGUE, M. A. (2004). Performance evaluation of a Bambara groundnut sheller. International Commission of Agricultural Engineering,

$6(1)$. https://hdl.handle.net/1813/10415

AZAM-ALI, S.N., AGUILLAR-MANJARREZ, J., \& BANNAYAN-AVVAL, M. (2001). Global mapping system for Bambara groundnut. FAO Agricultural Information Management series 1, 1-47. http://eprints.rclis.org/15746/1/A\%20Global\%20Map ping\%20System $\% 20$ for $\% 20$ Bambara\%20Groundnut $\% 20$ Production.pdf

BATTESE, G.E., \& COELLI, T.J. (1995). A Model for technical inefficiency effect in a stochastic Frontier production function for panel data. Empirical economics, 20(2), 325-332.
https://doi.org/10.1007/BF01205442

BERCHIE, J. N., ADU- DAPAAH, H. K., DANKYI, A. A., PLAHAR, W. A., NELSON-QUARTEY, F., HALEEGOAH, J., ASAFU-AGYEI, J. N. \& ADDO, J. K. (2010). Practices and constraints in bambara groundnuts production, marketing and consumption in the Brong Ahafo and Upper-East regions of Ghana. Journal of Agronomy, 9(3), 111-118. 10.3923/ja.2010.111.118

CAVES, D. W., CHRISTENSEN, L. R., \& DIEWERT, W. E. (1982a). The Economic Theory of index numbers and the measurement of input, output and productivity. Econometrica, 50(6): 1393-1414. https://doi.org/10.2307/1913388

CAVES, D. W., CHRISTENSEN, L. R., \& DIEWERT, W. E. (1982b). Multilateral comparisons of outputs, inputs and productivity using superlative index numbers. The Economic Journal, 92(365), 73-86. https://doi.org/10.2307/2232257

CHARNES, A., COOPER, W. W., \& RHODES, E (1978). Measuring the efficiency of decision making units. European Journal of Operational Research, 2(6): 429444. https://doi.org/10.1016/0377-2217(78)90138-8

COELLI, T. J. (1995). Recent development in frontier modelling and efficiency measurements. Australian Journal of Agricultural Economics, 39(3), 219-245. https://doi.org/10.1111/j.1467-8489.1995.tb00552.x

COELLI, T. J., \& RAO, D. S. P (2005). Total factor productivity growth in agriculture: A Malmquist index analysis of 93 Countries, 1980-2000. The Journal of the International Association of Agricultural Economists, 32(1), 115-134. https://doi.org/10.1111/j.0169-5150.2004.00018.x

ANI, D. P., UMEH, J. C., \& EKWE, K. C. (2013). Bambara groundnut as panacea for food security: profitability and production efficiency in Benue state, Nigeria. ISHS Acta Horticulturae 979: II International Symposium on Underutilized Plant Species: Crops for the Future - Beyond Food Security. https://doi.org/10.17660/ActaHortic.2013.979.21

DANSI, A., VODOUHE, R., AZOKPOTA, P., YEDOMONHAN, H., ASSOGBA, H., ADJATIN, A., LOKO, Y. L., DOSSOU-AMINON, I., \& AKPAGANA, K. (2012). Diversity of the neglected and underutilized crop species of importance in Benin. The Scientific World Journal, 2012, 932947. https://doi.org/10.1100/2012/932947

EKUNWE, P. A., \& EMOKARO, C. O. (2009). Technical efficiency of catfish farmers in Kaduna. Journal of Applied Sciences Research, 5(7), 802-805. http://www.aensiweb.com/old/jasr/jasr/2009/802$\underline{\text { 805.pdf }}$

EWUZIEM, J. E., ONYENOBI, V. O. (2012). Cost and return analysis of ginger production in the Guinea Savannah of Nigeria. Journal of Agriculture and Food Science, $\quad$ 10(2), 26-36. http://dx.doi.org/10.4314/jafs.v10i2.3

FARRELL, M. J. (1957). The measurement of productive efficiency. Journal of the Royal Statistical Society, 120(3), 253-290. https://doi.org/10.2307/2343100

FOOD AND AGRICULTURE ORGANISATION (n.d). Traditional crops: bambara groundnut. 
http://www.fao.org/traditionalcrops/bambaragroundnut/en/

IBRAHIM, A. R., DANSI, A., SALIFOU, M., DUSMANE, A., ALZOUMA, A., \& ALOU W (2018). Farmers' practices, utilization, conservation and marketing of bambara groundnut (Vigna subterranean (1) verdc) in Dosso Region, Western Niger. Genetic Resources and crop evolution, 65(7):1907-1914. https://doi.org/10.1007/s10722-018-0664-Z

IBRAHIN, H. D., \& OGUNWUSI, A. A. (2016). Industrial potentials of Bambara nut. Journal of Poverty, Investment and Development, 22, 12-18. https://iiste.org/Journals/index.php/JPID/article/view/ 29338

Knoema. n.d. Nigeria-Kaduna. World Data Atlas. [online]. https://knoema.com/atlas/Nigeria/Kaduna

Knoema. n.d. Nigeria-Kogi. World Data Atlas. [online]. https://knoema.com/atlas/Nigeria/Kogi

KORIR, M. K., SEREM, A. K., SULO, T. K., \& KIPSAT, M. J. (2011). A stochastic frontier analysis of bambara groundnut production in western Kenya. Congress proceedings 18th International Farm Management Congress Methven, Canterbury, New Zealand, March 2011. https://ifmaonline.org/contents/pr-a-stochasticfrontier-analysis-of-bambara-groundnut-productionin-western-kenya-p7480/

MABHAUDHI, T., \& MODI, A. T. (2013). Growth, phonological and yield responses of bambara groundnut (Vigna subterranean) land races to imposed Water stress under field condition. South African Journal of Plant and Soil, 30(2), 69-79. https://doi.org/10.1080/02571862.2013.790492

MAYES, S., HO, W. K., CHAI, H.H., GAO, X., KUNDY, A. C., MATEVA, K. I., ZAHRULAKMAL, M., HAHIVEE, M.K.I.M., KENDABIE, P., LICEA, L. C. S., MASSAWE, F., MABHAUDHI, T., MODI, A. T., BERCHIE, J. N., AMOAH, S., FALOYE, B., ABBERTON, M., OLANIYI, O., \& AZZAM-ALLI, S. N. (2019). Bambara groundnut an exemplar underutilized for resilience under climate change. Planta, 250(3):803-820. https://doi.org/10.1007/s00425-019-03191-6

MAZAHIB, A.M., NUHA, M.O., SALAWA, I.S., \& BABIKER, E.E. (2013). Some nutritional attributes of bambara groundnut as influenced by domestic processing. International Food Research Journal, 20(3),

1165-1171. http://www.ifrj.upm.edu.my/20\%20(03)\%202013/18 \%20IFRJ\%2020\%20(03)\%202013\%20ElFadil\%20(4 56).pdf

MEEUSEN, W., \& VAN DEN BROECK, J. (1977). Efficiency estimation from Cobb-Douglas production function with composed error. International Economic Review, $18(2)$

https://doi.org/10.2307/2525757

43544.

MKANDAWIRE, F. L., \& SIBUGA, K. P. (2002). Yield response of bambara groundnut (Vigna subterranean) to plant population and seedbed type. African Crop Science Journal, https://doi.org/10.4314/acsj.v10i1.27556

MOHAMMED, H. (2016). Analysis of profitability and production efficiency of small scale bambara nut farming in Kajuru local government area of Kaduna state (unpublished master's thesis). Ahmadu Bello University, Zaria, Kaduna.

MULINGA, N. (2013). Economic analysis of factors affecting technical efficiency of smallholder maize production in Rwanda. Rwanda Journal, 1(1):52-62. http://dx.doi.org/10.4314/rj.v1i1.4H

MUNE, M.A., MINKA, S. R., MBOME, I. L., \& ETOA, F. X. (2011). Nutritional potential of bambara bean protein concentrate. Pakistani Journal of Nutrition, $10(2)$,

112-119.

http://dx.doi.org/10.3923/pjn.2011.112.119

MUREVANHEMA, Y. Y., \& JIDEANI, V. A. (2013). Potential of bambara groundnut (Vigna subterranean (L) (verde) milk as a probiotic beverage. a review: critical review. Food Science and Nutrition, 53(9). 954-967.

https://doi.org/10.1080/10408398.2011.574803

MUSABA, E., \& BWACHA, I. (2014). Technical efficiency of small scale maize production in Masaiti district, Zambia: a stochastic frontier approach. Journal of Economics and Sustainable Development, 5(4),

104-111. https://www.iiste.org/Journals/index.php/JEDS/article /view/11272

NIN, A., ARNDT, C., \& PRECKEL, P. V. (2003). Is agricultural productivity in developing countries really shrinking? New Evidence using a modified nonparametric approach. Journal of Development Economics, 71(2), 395-415. https://doi.org/10.1016/S0304-3878(03)00034-8

NJERU, J. (2010). Factors influencing technical efficiencies among selected wheat farmers in Uasin Gishu districts Kenya. African Economic Research Consortium (AERC). Research Paper. https://core.ac.uk/download/pdf/6476029.pdf

NJI, F. F, NIESS, E., \& PFEFFER, E. (2003). Effect of raw and heat treated bambara groundnut (Vigna subterranean) on the performance and body composition of growing broiler chicks. Arch Tierernahr, 57(6),443-453. DOI: https://doi.org/10.1080/0003942032000161081

NJI, F. F, NIESS, E., \& PFEFFER, E. (2004). Nutrient content of Bambara groundnut (Vigna subterranean) and the effect of its inclusion on the performance of growing broiler chicken and on egg production and quality. Journal of Animal and Feed Science, 13(3), 497-507. https://doi.org/10.22358/jafs/67619/2004

NKAMIGBO, D. C., OVUOMARIE, O. S., MADUKA, J. U, \& ISIBOR, A. C. (2014). Economic efficiency and profitability of Catfish (Clarias garienpinus) Production in Isoko area of Delta State, Nigeria. Journal of Agriculture and Veterinary Sciences, 6(2), $32-40$

NURUDEEN, S., \& RASAKI, K. (2011). Technical efficiency of Cowpea production in Osun State. Nigeria Journal of National Science Research, 1(2), 29-34.

https://iiste.org/Journals/index.php/JNSR/article/view $\underline{1817}$

NWARU, J. C., \& NDUKWU, P. C. (2011). Estimation of farm level of technical efficiency and its determinants 
among male and female sweet potatoes farmers in Imo State, Nigeria. Ethiopian Journal of Economics, 20 (1), 99-112. https://www.ajol.info/index.php/eje/article/view/8296 $\underline{8}$

OGŪNDARI, K., \& OJO, S.O. (2007). Economic efficiency of small scale food crop production in Nigeria: a stochastic frontier approach. Journal of Social Sciences, 14(2), 123-130. https://doi.org/10.1080/09718923.2007.11978363

OGUNDARI, K. (2008). Resource productivity, allocative efficiency and determinants of technical efficiency of rainfed rice farmers: A guide for food security policy in Nigeria. Agricultural Economics, 54(5), 224-233. $\quad$ https://doi.org/10.17221/246AGRICECON

OHAJIANYA, D. O., \& ONYENWEAKU, C. E. (2003). Analysis of cost and returns in rice farming by farm size in Ebonyi State. Journal and Agriculture and Social Research, 3(1), 29-39. https://doi.org/10.4314/jasr.v3i1.2784

ONUCHE, U., ALI, S. O., \& ISAAC, J. T. (2015). Technical Efficiency Estimates and the role of Formal Education: Evidence from Catfish firms in Ijumu Local Government Area of Kogi state, north central, Nigeria. Agrosearch, 15(2), 107 - 117. https://doi.org/10.4314/agrosh.v15i2.9

OYINBO, O., ADAH. I. D., \& REKWOT, G. Z. (2015). Technical efficiency-food security nexus in Kaduna state, Nigeria: a case study of poultry egg farmers. Consilience: The Journal of Sustainable Development, 14, 244-259. https://www.jstor.org/stable/26188754
SCHULTZ, T. W. (1964). Transforming Traditional Agriculture. Chicago. University of Chicago press.

SEGUN-OLASAMI, A. O., \& BAMIRE, A. S. (2010). Analysis of Cost and returns to Maize-Cowpea intercrop production in Oyo State, Nigeria. Paper presented at the Joint $3^{\text {rd }}$ African Association of Agricultural Economics ( $A A A E)$ and $48^{\text {th }}$ Agricultural Economic Association of South Africa (AEASA) conference, Cape Town, South Africa September 1923, 2010.

SIMONYAN, J. B., OLUKOSI, J. O., OMOLEHIN, R. A. \& ATALA, T. K. A. (2012). Productivity and technical efficiency among beneficiary farmers of second National Fadama Project in Kaduna State, Nigeria. American Journal of Experimental Agriculture, 2(1), 102-110. https://doi.org/10.9734/AJEA/2012/854

TWENEBOAH, C. K. (2000). Modern Agriculture In the tropics. Food crops. Co-wood publishers.

YAKUBU, H., KWARI, J. D., \& SANDABE, M. K. (2010). Effect of phosphorus fertilizer on nitrogen fixation by some grain legumes variety in SudanoSahelian Zone of Northeastern Nigeria. Nigerian Journal of Basic and Applied Sciences, 18(1), 19-26. https://doi.org/10.4314/njbas.v18i1.56837

YAMAGUCHI, M. (1983). World Vegetables: Principles, Production and Nutritive values. Molecular Nutrition, 28, 1028. https://doi.org/10.1007/978-94-011-7907-2 